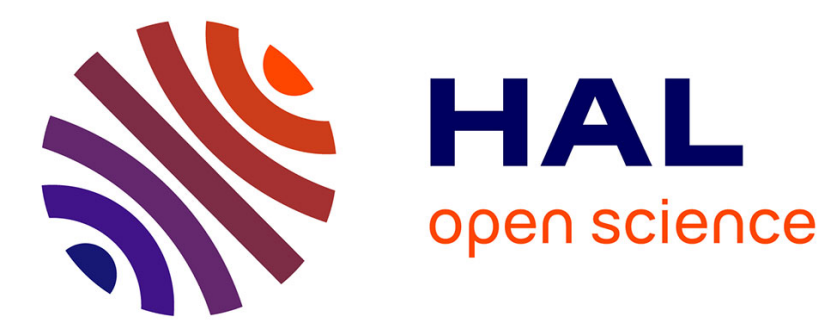

\title{
Modern pollen assemblages from grazed vegetation in the western Pyrenees, France: a numerical tool for more precise reconstruction of past cultural landscapes
}

Florence Mazier, Didier Galop, Cécile Brun, Alexandre Buttler

\section{- To cite this version:}

Florence Mazier, Didier Galop, Cécile Brun, Alexandre Buttler. Modern pollen assemblages from grazed vegetation in the western Pyrenees, France: a numerical tool for more precise reconstruction of past cultural landscapes. The Holocene, 2006, 16 (1), pp.91-103. halshs-00959347

\section{HAL Id: halshs-00959347 \\ https://shs.hal.science/halshs-00959347}

Submitted on 14 Mar 2014

HAL is a multi-disciplinary open access archive for the deposit and dissemination of scientific research documents, whether they are published or not. The documents may come from teaching and research institutions in France or abroad, or from public or private research centers.
L'archive ouverte pluridisciplinaire HAL, est destinée au dépôt et à la diffusion de documents scientifiques de niveau recherche, publiés ou non, émanant des établissements d'enseignement et de recherche français ou étrangers, des laboratoires publics ou privés. 


\title{
Modern pollen assemblages from grazed vegetation in the western Pyrenees, France: a numerical tool for more precise reconstruction of past cultural landscapes
}

\author{
Florence Mazier, ${ }^{*}$ Didier Galop, ${ }^{1}$ Cécile Brun ${ }^{1}$ and \\ Alexandre Buttler ${ }^{1,2}$
}

('Laboratoire de Chrono-Ecologie, UMR 6565 CNRS, Université de FrancheComté, 16 route de Gray, F-25030 Besançon Cedex, France; ${ }^{2}$ Laboratoire des Systèmes écologiques - ECOS, Ecole polytechnique fédérale de Lausanne (EPFL) et Institut fédéral de recherches WSL, Antenne romande, Case postale 96, CH-1015 Lausanne, Switzerland)

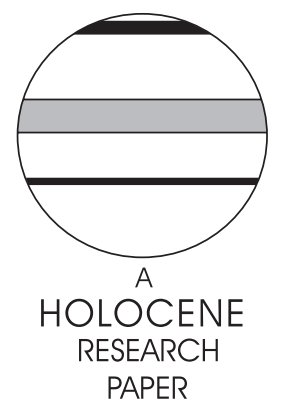

\section{Introduction}

The reliability of pollen analysis as a tool for the reconstruction of past vegetation depends on good calibration between present pollen deposition and vegetation, and on the precise understanding of how current species composition is reflected in pollen assemblages. In attempting to evaluate not only

*Author for correspondence: (e-mail: florence.mazier@univ-fcomte.fr)

\begin{abstract}
Modern pollen assemblages from grazed vegetation in the Pyrenees Mountains (France) were studied with the aim of providing a calibrated model for reconstructing past pastoral activities. The modern analogues were selected to cover the major gradients of grazing pressure and degree of openness. The vegetation was surveyed by means of the synusial integrated method, assessing the structure and the patchiness of the pastoral phytoceonoses. A correlative model (Redundancy analysis) was devised relating wooded, open grazed and nitrophilous sites are clearly separated from one another and that the model can be simplified using three relevant vegetation types as explanatory variables: dry heathland, semi-open oak forest and overgrazed community, respectively related to gradients of openness, soil richness and grazing pressure. When reconstructing past pastoral activities with fossil pollen spectra, it is important to consider scale-dependent influences of plant species. Low frequencies of well-dispersed taxa such as Artemisia, Chenopodiaceae, Plantago lanceolata and Plantago major/media must be interpreted with care since they reflect more regional, rather than local, input into the pastoral landscape. In contrast, the simultaneous occurrence of Asteroideae, Cichorioideae, Cirsium-type, Galium-type, Ranunculaceae, Stellaria-type and Potentilla-type pollen is clearly related to grazing on a local scale. Calculation of Davis indices also shows that Cichorioideae, Galium-type and Potentilla-type indicate the very local presence of the corresponding plants. These pastoral plant indicators may have a limited geographical validity, ie, mountainous regions with crystalline bedrock, which may indeed also provide the framework for the application to fossil spectra of the modern pollen/vegetation/land-use models presented here.
\end{abstract}

Key words: Integrated synusial approach, modern pollen, vegetation history, land use, pastoral indicators, scale, numerical analyses, western Pyrenees, France. 
especially those favoured by human activity and today found mainly in human-induced vegetation types (Behre, 1981; Vorren, 1986; Hicks, 1988). Another interpretation tool is the 'comparative approach': comparisons of modern and fossil pollen spectra using all taxa, therefore a community-based approach (Wright, 1967). A wide range of communities/pollen assemblages is needed to increase our understanding of past landscapes and past land-use changes. In northern Europe, modern pollen assemblages and related vegetation, as well as land-use data, have been used to provide a basis for numerical comparisons (Berglund and Ralska-Jasiewiczowa, 1986; Berglund et al., 1986; Gaillard et al., 1992, 1994; Hicks and Birks, 1996; Hjelle, 1999a; Räsänen, 2001). These studies identified pollen assemblages and taxa indicators of various human-induced vegetation types. Despite these valuable contributions to the interpretation of pollen diagrams, the pollen/ vegetation/land-use relationships found in northern Europe are not necessarily applicable in other areas, such as the mountainous regions of Mediterranean Europe (Galop, 1998; Galop et al., 2003; Court-Picon, 2005). Many pollen diagrams from the western Pyrenees Mountains have been produced recently (Galop, 1998; Galop et al., 2003), but no reconstruction of past vegetation or landscape units by means of comparisons of modern and fossil pollen spectra has been attempted so far.

Therefore, the objectives of the present study in the Pyrenees Mountains were:

- to investigate pollen representation of trees and herbs in modern pollen assemblages from characteristic vegetation types;

- to assess the major gradients in modern pollen assemblages and relate these to measured environmental variables;

- to test whether different vegetation types with their specific vegetation structure, as described by the integrated synusial approach, can be used efficiently to express the vegetation/ pollen relationship;

- to establish whether various degrees of openness and grazing pressure produce significantly distinct modern pollen spectra, and to identify pollen taxa characteristics of pastoral activities.

The comparative approach requires a search for modern analogues of past landscapes and vegetation communities. Owing to the elevation and the steep slopes, grazing seems to have always been the main land-use practice in the Iraty Mountains of the Basque Country. Today, farmers maintain traditional land-use practices based on transhumance from the valley to the summer pastures. The main activity is sheep raising for milk and cheese. This production system necessitates, for each shepherd and his flock, small enclosures for gathering the herd, a milking corridor, a hut for cheese production and specific patches in summer pastures. It also calls for extensive and intensive pastures, some with forested areas and some treeless.

The modern analogues used for establishing the pollen/landuse relationship should present, as far as possible, ecological conditions similar to those prevailing in the past (Gaillard et al., 1992). Moss polsters are commonly used as surface samples for local modern pollen deposition (Gaillard et al., 1992; Hicks and Birks, 1996; Hjelle, 1998). They are assumed to record an average of several years of pollen deposition (Bradshaw, 1981; Heim, 1970), which is recommended since previous investigations have shown annual variation in pollen productivity (Hicks, 2001; Hicks et al., 2001; van der Knaap et al., 2001; Räsänen et al., 2004). Moreover, the modern pollen assemblage should be a good analogue of a fossil pollen assemblage, which usually covers more than one year of pollen deposition. However, contradictory views exist as to the timespan of pollen deposition covered by mosses (Cundill, 1991; Räsänen et al., 2004).

\section{Methods}

\section{Study area and sampling design}

The data presented in this study were collected within the interdisciplinary research programme 'Palaeo-environment and dynamics of human activities in the Pyrenees Mountains' (Galop et al., 2004). A field site for the programme was selected in the Iraty Mountains in the Basque Country (western part of the Pyrenees chain in southern France) and lies between 700 and $1500 \mathrm{~m}$ a.s.l. The silicate bedrock and acidic soils present there induce abundant peat deposits in small basins.

The landscape is hilly and characterized by a mosaic of vegetation types variously affected by pastoral activity. On sloping grounds the vegetation is dominated by heather moorland of Calluna vulgaris, Erica sp., Molinia coerulea and patches of Ulex europaeus and Pteridium aquilinum, still used for animal litter. Some slopes, especially the steepest ones, are dominated by deciduous forest patches of beach and oak. Intensive grazed pastures are prevalent on the smooth mountain crests.

Our investigations focused on a small watershed centred on the topogenic Sourzay's peat bog with the aim of investigating modern pollen/vegetation and pollen/land-use relationships in a mosaic pasture-woodland landscape, and to use these relationships in the interpretation of fossil pollen records from the same area. The modern analogues were selected near the fossil sequence to assess the effect of the vegetation structure on the pollen record. For collection of the modern pollen and related vegetation data, a preferential design was selected with stratification based on degree of landscape openness and current land use along four axes across the watershed and centred on the fossil pollen record site (Figure 1). Thus, the major relevant vegetation communities and gradients of grazing pressure, from open to forested areas, were covered. The transects were chosen so as to exclude as much as possible any areas disturbed by thalwegs, streams and human activities other than pastoral ones. Some relevant vegetation types such as grazed oak forests or enclosures were absent from the study site. The modern analogue data set was therefore completed outside the watershed.

\section{Field method}

\section{Vegetation data}

A set of 71 vegetation relevés from various forest types (oak, beech), heath and wet vegetation communities was collected from both grazed and ungrazed areas during the summer of 2001. Vegetation analysis was undertaken according to the integrated synusial approach (Gillet et al., 1991, 2002; Gillet and Gallandat, 1996), which is a method based on the Braun-Blanquet approach (Braun-Blanquet, 1964), but allows better structural description and characterization of plant communities in their landscape context (Figure 2). This method aims at:

- describing complex vegetation structures, taking into account both horizontal and vertical heterogeneity;

- emphasizing functional and dynamic links between various constituent elements among several spatio-temporal organization levels. 


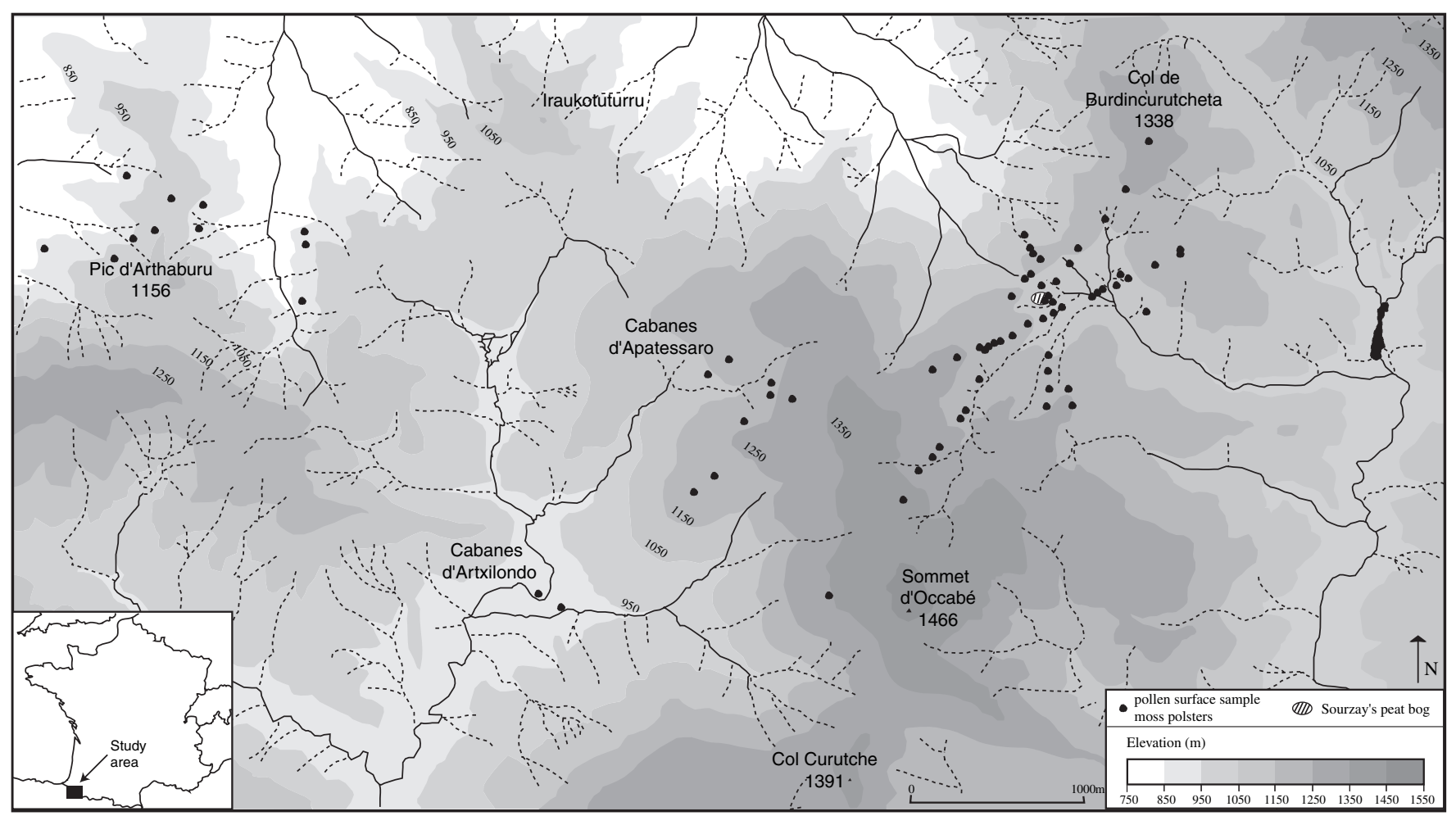

Figure 1 The study area in southern France and the Iraty mountains of the Pays Basque. Location of the 71 modern analogues (solid circles) where pollen samples (moss polsters) and related vegetation data were collected. In the vicinity of the fossil pollen sequence (Sourzay's peat bog), the modern analogues are located along four transects with a stratification based on the degree of grazing and openness

Only two levels were considered in this study, those of the synusia and the phytocoenosis. The synusia is an elementary one-layered concrete vegetation unit (patch) directly linked to uniform environmental conditions. Thus, every synusia is a floristically, physiognomically and ecologically homogeneous vegetation unit. In the field, several vegetation stands were divided vertically and horizontally into synusiae, each therefore undergoing sampling for a floristic relevé. The synusial relevé

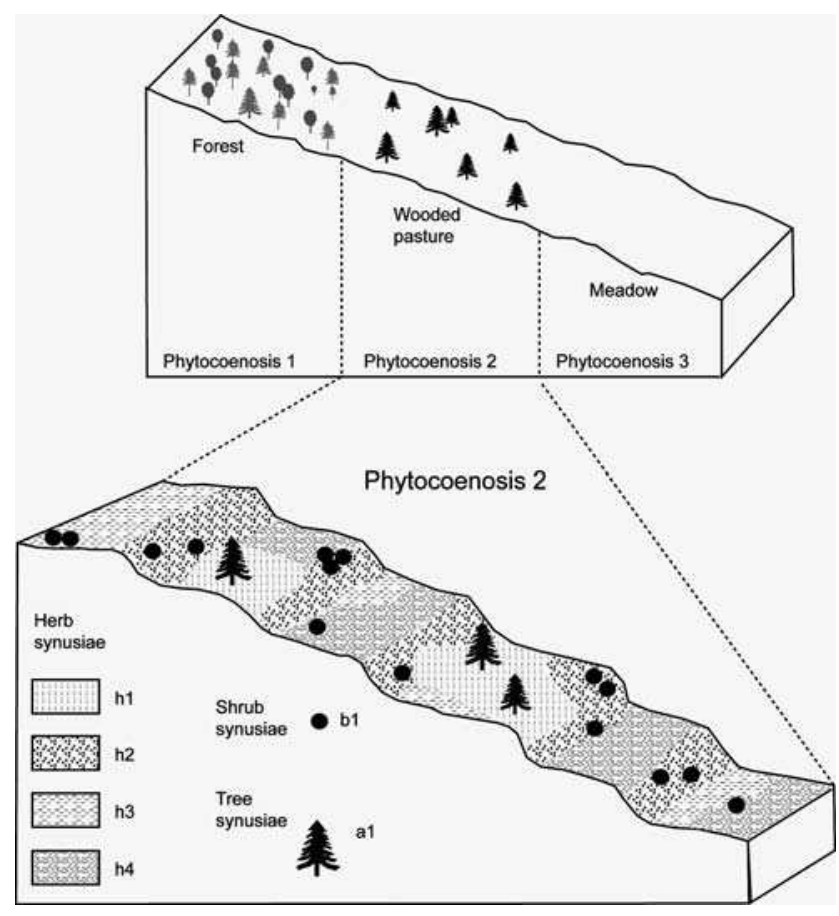

Figure 2 Schematic representation of the two integration levels used for vegetation description, according to the integrated synusial method (adapted from Gillet and Gallandat, 1996) furnishes a semi-quantitative description, according to BraunBlanquet (1964), of the species occurring in the sample patch. Synusiae are organized in space and in time within phytocoenosis, as elements of a mosaic or a zoning of stratal communities (Gillet and Gallandat, 1996). Thus, a phytocoenosis is a complex of synusiae (herb, shrub and tree synusiae), functionally strongly linked in both space (mosaics, stratification) and time. A phytocoenotic relevé also furnishes a semiquantitative description of the synusiae observed in a concrete phytocoenosis. The investigated sites presented homogeneous vegetation (floristically and structurally) on a minimal surface of $100 \mathrm{~m}^{2}$ (not necessarily a square), which was the surveyed surface for each phytocoenosis. Vascular plant nomenclature follows Tutin et al. (1964-1980).

\section{Sampling of moss polsters}

In the present study, moss polster samples were taken down to but not including the soil, and collected at the end of the flowering season, September 2001 (Räsänen et al., 2004). Moss species vary from site to site, but whenever possible species producing dense life forms were chosen (Boyd, 1986). For the wet sites, Sphagnum sp. was the only available species and the upper green part (the first $4 \mathrm{~cm}$ ) was collected.

For each phytocoenosis, and on the entire surface of the vegetation relevé, ten mosses were sampled and mixed together into one sample per site (Gaillard et al., 1992).

\section{Environmental variables}

The sampling sites were classified into categories according to the degree of grazing, dunging and trampling pressure, assessed as the proportion of the surveyed surface showing signs of recent cattle activity. On an ordinal scale, classes ranged from 0 to 3 as follows: (0) no pressure, (1) pressure $<5 \%$ of the surface, (2) pressure between 5 and $50 \%$ of the surface, (3) pressure $>50 \%$ of the surface. Livestock type (absence/presence nominal variable) was also taken into 
account, designated as sheep, horse, cow or pig, since livestock in this region was not mixed for all 71 sites. The altitude, slope (quantitative variables), aspect, nature of bedrock (absence/ presence nominal variable) were measured or identified for each phytocoenosis. The aspect was transformed into a quantitative variable based on a trigonometric measure for both the north and east scales (eg, for the N-NE aspect the measure on the north scale was $\sin 67.5=0.92$ and on east scale $\cos 67.5=0.38$ ). In order to investigate how variation in the pollen data might be explained by the main gradients in the vegetation data, phytocoenosis typology was used, providing explanatory qualitative variables. Each plant community, 13 in all, was expressed as a presence/absence nominal variable.

For each phytocoenosis, mean soil depth (ten measures taken, randomly spread over the surveyed surface) was measured and soil samples were taken from the top $10 \mathrm{~cm}$ of soil, which corresponded to the A horizon, homogenized and pooled into one sample per surveyed surface (Gaillard et al., 1992, 1997). A subsample was then air dried. The fraction (\%) of coarse material $(>2 \mathrm{~mm}$ ) was determined by the sieving procedure. The fresh sample was used for $\mathrm{pH}(\mathrm{KCl})$ and $\mathrm{pH}$ $\left(\mathrm{H}_{2} \mathrm{O}\right)$ measurements. Organic matter $(\%)$, derived from the ash content, and total $\mathrm{N}(\%)$ were analysed. These classical methods followed standard procedures (Anderson and Ingram, 1993). The water-holding capacity was obtained by saturating the soil sample over 96 hours, removing the excess water by filtration and oven drying the sample. The potential water content ( $\%$ of dry soil) was obtained by the weight difference between saturated and dry soil.

Altogether, 37 explanatory variables were recorded and divided into five general categories: edaphic, geologic, geomorphologic, land use and vegetation variable types.

\section{Laboratory methods}

Moss samples were treated according to standard procedures (Faegri and Iversen, 1989) by boiling in 10\% $\mathrm{NaOH}$ for $45 \mathrm{~min}$, sieving, treating with $40 \% \mathrm{HF}$ (to digest fine silica), $\mathrm{ZnCl}_{2}$ (to eliminate clay material), and acetolysis (one part $\mathrm{H}_{2} \mathrm{SO}_{4}$ and nine parts acetic anhydride, heated in water bath for $8 \mathrm{~min}$ ). Samples were mounted in glycerol, and pollen were identified to the most precise taxonomic level possible, using pollen keys (Faegri and Iversen, 1989; Moore et al., 1991; Reille, 1992).

As the focus of this study is the effect of the vegetation structure on the pollen assemblages, pollen from trees, dwarfshrubs and herbs were thus included in the analysis. A minimum of 400 pollen grains was counted per sample, and a total of 113 pollen and spore taxa were recorded. Moreover, as one of the main goals was to investigate the plant-pollen relationships on a local scale, some taxa were excluded from the pollen sum. Only pollen taxa of plants potentially present in the flora of the region were included in the analysis. For example, pollen of Olea was excluded and considered exogenous as it comes from cultivated areas in Spain, far from the study area. The calculation sum, used to obtain percentages of the pollen taxa in numerical analyses, excludes exogenous and aquatic taxa as well as fern spores. In all, 28 taxa were excluded. Thus, the modern pollen data set consists of 71 samples and 85 pollen taxa.

\section{Data analysis}

\section{Vegetation typology}

The vegetation was described through examination of 71 phytocoenotic relevés and 256 synusial relevés among these phytocoenoses. Synusial typology was first carried out based on the comparison and classification of the synusial relevés using floristic-statistical tools to identify syntaxa (typological units of this organization level). These tools combine step by step various applications such as ordinations and clustering using different options of the package MULVA-5 (Wildi and Orloci, 1996). The analytical procedure was performed separately on the data of each layer, herb, shrub and tree. The optimal number of groups of relevés and species was determined by comparing the results of the various classifications using criteria such as concentration analysis and contingency coefficient provided in the package. The phytocoenotic relevés were compared using the same numerical tools and classified into coenotaxa (typological units of this organization level).

\section{Association and representation indices}

In order to understand the pollen-plant relationships at the taxonomic level used for pollen analysis, plant taxa were grouped according to pollen morphological types. For the vegetation, the species list was first derived from all the synusial relevés included in each phytocoenotic relevé. Taxa occurring only as plants or only in the pollen assemblages were excluded from the calculation of the Davis indices of association (A), under-representation (U) and over-representation $(\mathrm{O})$ (Davis, 1984; Hjelle, 1997; Bunting, 2003). These indices are based on presence-absence data of the taxon list and are defined as follows:

$$
\begin{aligned}
& \mathrm{A}=\mathrm{B}_{0}\left(\mathrm{P}_{0}+\mathrm{P}_{1}+\mathrm{B}_{0}\right)^{-1} \\
& \mathrm{U}=\mathrm{P}_{1}\left(\mathrm{P}_{1}+\mathrm{B}_{0}\right)^{-1} \\
& \mathrm{O}=\mathrm{P}_{0}\left(\mathrm{P}_{0}+\mathrm{B}_{0}\right)^{-1}
\end{aligned}
$$

Where $\mathrm{B}_{0}$ is number of samples in which both the pollen type and its associated plant are present, $\mathrm{P}_{0}$ is number of samples in which the pollen type is present in the surface sample but not the plant taxa and $P_{1}$ is number of samples in which the pollen type is not present in the surface sample but the plant taxa is present in the vegetation.

Ordination by principal component analysis (PCA) was used to display the relationship between the calculated indices (A, $\mathrm{U}, \mathrm{O}$ as descriptors) and the pollen taxa (objects). PCA used a covariance matrix with the eigenvectors adjusted by variance. The taxa were then classified into groups using agglomerative hierarchical clustering with proportional-link linkage, and a connection of 0.7. Euclidian distance was used. PCA and cluster analysis were implemented respectively by the CANOCO program for Windows 4.0 (Leps and Smilauer, 2003; Ter Braak and Smilauer, 1998) and Progiciel R (Casgrain and Legendre, 2001).

\section{Pollen/vegetation/environment relationships}

Direct gradient analyses were considered appropriate for exploration and testing patterns of modern pollen variation in relation to environmental and anthropogenic explanatory variables. The fitting model depends on whether the pollen taxa respond roughly linearly to gradients (linear response), or perform best around some environmental optima (unimodal response) (Ter Braak and Smilauer, 1998). Preliminary Detrended Canonical Correspondence Analysis (DCCA) showed that this data set has a gradient length of 1.309 standard deviation units of species turnover (SD). This implied that linear-based methods of data analysis such as Redundancy Analysis (RDA) were suitable in this case (Ter Braak and Prentice, 1988).

RDA attempts to explain pollen taxa responses by ordination axes that are constrained to be linear combinations of the 37 explanatory variables available, including the 13 coenotaxa (vegetation communities). Thirteen pollen taxa present only 
once in the 71 pollen assemblages were omitted. The pollen percentage data was $\log$-transformed $[\ln (a y+c)$ with $a=1$ and $c=1)$ and double-centred. Forward selection and Monte Carlo test with 999 unrestricted permutations were run to check statistical significance and to select the best explanatory variables for further analysis. The permutation tests were later applied to the canonical axes.

First, the investigated matrix contained the pollen data set and 37 independent variables from 71 modern analogues. In preliminary RDA, pollen assemblages from enclosures and wetland communities were clearly separated from the remaining sites, but were also clearly different from fossil spectra (included passively) (Mazier, Galop, Cugny, Buttler, Legaz and Rendu, unpublished data, 2005). These sites contained some characteristic taxa in large proportion and their assemblages were quite different from the other plots, causing a long gradient in the ordinations, which resulted in a poor separation of the other samples. Ten sites and consequently two explanatory variables were therefore omitted for further RDA, resulting in the use of 61 sites, 73 pollen taxa and 35 environmental variables, of which 13 were retained for their significance, the others being passively presented in the ordination diagrams (or given as covariable).

Three main predictor variables, three vegetation groups, which had the best correlation with the first three ordination axes, were used for more precise analyses. In order to define the weight of each taxon for these three nominal variables, partial RDA was performed separately on each one. The species scores on the first canonical axis of each analysis were then considered descriptors in a new ordination using Principal Component Analysis (PCA). PCA used a covariance matrix with the eigenvectors adjusted to the square root of their variance, divided by the standard deviation (symmetric scaling $\left.\sqrt{ } \lambda_{\mathrm{h}} / s_{\mathrm{i}}\right)$.

All ordination analyses were implemented by the CANOCO program for Windows 4.0 (Ter Braak and Smilauer, 1998) and diagrams constructed by Progiciel R (Casgrain and Legendre, 2001) and refined by Illustrator 10 .

\section{Results}

\section{Phytocoenosis typology}

The numerical analysis of the 256 synusial relevés resulted in 21 syntaxa (cluster group): 4 within trees, 3 within shrubs and 14 within the herb layer (Table 1 presents the species composition for the herb syntaxa). The comparison and the classification of the 71 phytocoenotic relevés made it possible to identify 13 coenotaxa (Table 2) divided into two main groups: anthropogenic (4) and 'natural' communities (9). These plant communities can be ordered along a gradient of anthropogenic influence and degree of openness. Here, we describe only the three main coenotaxa, which are found as significant explanatory variables in the redundancy analysis.

Coenotaxon No. 2 occurs mainly on small areas and reflects a community type composed of two herb syntaxa. The syntaxon $\mathbf{H 4}$ (Rumex acetosella-Galium saxatile) is correlated with intense livestock activity inducing areas of urination and defecation, as well as bare soil areas. The vegetation of the patch presents a short and sparse canopy dominated by Rumex acetosella and Galium saxatile. The other syntaxon H3 (Trifolium repens-Poa апnиa) reflects grazed dense vegetation. This short grass patch is dominated by grazed-area species such as Poa annua, Trifolium repens, Stellaria media ssp. media and Cerastium fontanum ssp. fontanum. Coenotaxon No. 2 depends directly on the daily routine of the livestock, mainly sheep, and presents a high pastoral value. This overgrazed community is often found on mountain crests.

Coenotaxon No. 7 describes large areas of dry mountainslope heathland, composed of seven syntaxa. The principal syntaxa are $\mathbf{H 9}$ (Ulex europaeus-Calluna vulgaris), H5 (Potentilla erecta-Agrostis curtisii) and $\mathbf{H 1 4}$ (Pteridium aquilinumAgrostis curtisii). This high-altitude community presents heathland species, with a dominance of Agrostis curtisii, Potentilla erecta, Danthonia decumbens, Deschampsia flexuosa, Vaccinium myrtillus, Calluna vulgaris, Ulex europaeus, Erica vagans, Erica cinerea, Erica tetralix and Pteridium aquilinum. Its species composition is closely related to coenotaxon No. 6, which includes $\mathbf{H 8}$ in addition (Calluna vulgaris-Vaccinum myrtillus), and results from colonization by Ulex europaeus and Pteridium aquilinum, induced through a decrease in grazing pressure.

Coenotaxon No. 12 corresponds to open oak forest with a low and sparse canopy. This community includes three herb syntaxa (H5, H9 and H6 (Vaccinium myrtillus-Deschampsia flexuosa)), one shrub (B21) and two tree syntaxa (patches of oak trees alone (A17), and mixed beech and oak (A16)). The herb vegetation is dominated by Agrostis curtisii, Potentilla erecta, Calluna vulgaris, Ulex europaeus, Deschampsia flexuosa and Vaccinium myrtillus. This coenotaxon corresponds to poor soils on slopes outside the Sourzay watershed.

\section{Association and representation indices}

Only 32 taxa were found both as plants and as pollen in one or more phytocoenoses. The relationships between the different taxa and the calculated indices are summarized in the PCA scatter plot (Figure 3). The first axis explains $55.9 \%$ of the index variation, and is strongly related to the presence of both pollen and corresponding plants (eg, Poaceae, Cyperaceae). It separates strongly associated taxa, plants and pollen present in over $65 \%$ of the samples (Galium-type and Potentilla-type), from unassociated taxa occurring infrequently in the vegetation and pollen rain (eg, Rosaceae, Rumex obtusifolius). The second axis captures $40.1 \%$ of the variation and differentiates over-represented taxa, most often found only as pollen (eg, Abies, Quercus tot, Urtica dioica, Brassicaceae and Plantago lanceolata), from under-represented taxa often found only as plants (eg, Sorbus, Polygala, Erica tetralix).

Good agreement is found in the results of the two methods, ordination and classification, with strongly associated taxa of group 5 and associated taxa of group 3 on the right-hand side of the first axis. Group 1 clearly indicates over-represented taxa on the positive side of the second axis. Group 2 is centred and represents weakly associated types with low $\mathrm{A}$ values and relatively high $\mathrm{U}$ and $\mathrm{O}$ values. Group 4 constitutes a mixed group with unassociated, under-represented and weakly associated types. Table 3 summarizes the calculated indices for selected taxa in this study and also in previous ones, based on the classification of Bunting (2003).

\section{Pollen/vegetation/environment relationships}

Redundancy analysis (RDA) was used to describe the major gradients in the modern pollen assemblages and to relate these patterns to the environmental and anthropogenic variables. This correlative model also tests whether different degrees of openness and grazing pressure produce statistically distinct modern pollen spectra.

Among the 37 explanatory variables, 14 contribute significantly to the correlative model, using forward selection and Monte Carlo permutation tests ( $P \leq 0.05,999$ permutations). Pudding rock, mainly represented in some places of our study area, was found significant. This variable was considered to be a covariable as we did not want to interpret its effect. Therefore, a 
Table 1 Synthetic presentation of the herb synusial elementary syntaxa (SyE) of the Iraty Mountains pastoral landscape

\begin{tabular}{|c|c|c|c|c|c|c|c|c|c|c|c|c|c|c|}
\hline Syntaxon no. & 1 & 2 & 3 & 4 & 5 & 6 & 7 & 8 & 9 & 10 & 11 & 12 & 13 & 14 \\
\hline Number of synusial relevés & 4 & 5 & 5 & 18 & 50 & 32 & 6 & 9 & 21 & 8 & 6 & 5 & 6 & 11 \\
\hline Urtica dioica & $\mathrm{V}: 2$ & $\mathrm{r}:+$ & & & & & & & & & & & & \\
\hline Cirsium eriophorum & IV:2 & $\mathrm{r}: 2$ & & & $\mathrm{r}:+$ & & & & & & & & & \\
\hline Cirsium palustre & $\mathrm{V}: 2$ & & & & & & & & & & $\mathrm{r}:+$ & $\mathrm{r}: 1$ & & \\
\hline Cirsium vulgare & IV:2 & & & & & & & & & & $\mathrm{r}: 1$ & & & \\
\hline Rumex obtusifolius ssp. obtusifolius & & $\mathrm{V}: 1$ & & $\mathrm{r}: 1$ & & & & & & & & & & \\
\hline Taraxacum officinale & & $\mathrm{V}: 1$ & $\mathrm{r}:+$ & $\mathrm{r}:+$ & $\mathrm{r}:+$ & & & & & & $r: r$ & & & \\
\hline Ranunculus repens & & $\mathrm{V}: 2$ & & & & & & & & & & & & \\
\hline Achillea millefolium ssp. millefolium & & IV:1 & & & & & & & & & & & & \\
\hline Cynosurus cristatus & & IV:2 & & & & & & & & & & & & \\
\hline Lolium perenne & $\mathrm{r}:+$ & IV:2 & $\mathrm{r}:+$ & & & & & & & & & & & \\
\hline Holcus lanatus & & III:2 & & & & & & & & & & & & \\
\hline Capsella bursa-pastoris & & III: + & & & & & & & & & & & & \\
\hline Plantago lanceolata & & III:1 & $\mathrm{r}:+$ & $\mathrm{r}: 1$ & & & & & & & & & & \\
\hline Stellaria media ssp. media & $\mathrm{r}: 1$ & $\mathrm{~V}: 2$ & $\mathrm{~V}: 1$ & II:2 & $\mathrm{r}:+$ & & $\mathrm{r}: 1$ & & & & & & & \\
\hline Cerastium fontanum ssp. fontanum & $\mathrm{r}:+$ & $\mathrm{V}: 1$ & $\mathrm{~V}: 2$ & IV:2 & $\mathrm{r}:+$ & $\mathrm{r}: 2$ & & & & & & & & \\
\hline Trifolium repens & $\mathrm{r}:+$ & $\mathrm{V}: 2$ & III:2 & III:2 & & $\mathrm{r}: 1$ & & $\mathrm{r}: 2$ & & & $\mathrm{II}: 2$ & & & \\
\hline Роа аппиа & & $\mathrm{V}: 2$ & $\mathrm{~V}: 3$ & III:2 & $\mathrm{r}:+$ & $\mathrm{I}: 2$ & $\mathrm{II}: 2$ & & & & & & & \\
\hline Rumex acetosella & & II: + & & $\mathrm{V}: 2$ & $\mathrm{r}: 2$ & $\mathrm{I}: 2$ & & $\mathrm{r}: 3$ & & & & & & \\
\hline Danthonia decumbens & & & $\mathrm{r}:+$ & $\mathrm{I}: 1$ & $\mathrm{~V}: 2$ & & & & $\mathrm{r}: 1$ & II:1 & II:2 & $\mathrm{r}:+$ & & $\mathrm{r}:+$ \\
\hline Galium saxatile & & $\mathrm{r}: 1$ & $\mathrm{r}: 1$ & $\mathrm{~V}: 2$ & $\mathrm{~V}: 2$ & IV:2 & IV:2 & $\mathrm{r}: 3$ & $\mathrm{r}: 2$ & $\mathrm{II}: 2$ & $r: 2$ & & & \\
\hline Agrostis curtisii & & & & III:2 & $\mathrm{V}: 2$ & III: 2 & III: 1 & & $\mathrm{r}: 3$ & & & $\mathrm{r}:+$ & $\mathrm{r}: 1$ & $\mathrm{II}: 3$ \\
\hline Potentilla erecta & & & II: + & IV:1 & $\mathrm{V}: 2$ & II: 1 & & & $\mathrm{r}: 1$ & $\mathrm{~V}: 2$ & $\mathrm{~V}: 2$ & & & \\
\hline Carex flacca & & & & II:1 & $\mathrm{V}: 2$ & IV:2 & II: 2 & $\mathrm{r}: 2$ & $\mathrm{I}: 1$ & $\mathrm{r}: 1$ & IV:1 & & & \\
\hline Deschampsia flexuosa & & & $\mathrm{r}: 1$ & $\mathrm{I}: 1$ & II: 1 & $\mathrm{~V}: 3$ & $\mathrm{~V}: 2$ & $\mathrm{r}: 2$ & $\mathrm{r}: 2$ & & $\mathrm{r}: 2$ & IV:1 & II: 1 & II:2 \\
\hline Fagus sylvatica $H$. & & & & & $\mathrm{r}:+$ & III:1 & $\mathrm{II}: 2$ & & $\mathrm{r}:+$ & & $r: r$ & & $r: 3$ & \\
\hline Vaccinium myrtillus & & & & $\mathrm{I}:+$ & II:2 & IV:2 & IV:2 & $\mathrm{V}: 3$ & III: 1 & & $\mathrm{r}:+$ & & & \\
\hline Oxalis acetosella & & & & & & & $\mathrm{V}: 3$ & & & & & & & \\
\hline Calluna vulgaris & & & & & II: + & $\mathrm{I}: 1$ & & $\mathrm{~V}: 3$ & $\mathrm{~V}: 2$ & IV:2 & IV:1 & & & $\mathrm{r}: 5$ \\
\hline Ulex europaeus & & & & & $\mathrm{r}:+$ & & & & $\mathrm{V}: 3$ & & & & & \\
\hline Erica vagans & & & & & $\mathrm{I}: 1$ & $\mathrm{r}: 2$ & & $\mathrm{r}:+$ & $\mathrm{V}: 2$ & & & & & \\
\hline Erica cinerea & & & $\mathrm{r}:+$ & & $\mathrm{r}: 1$ & & & $\mathrm{r}:+$ & IV:2 & & & & & \\
\hline Erica tetralix & & & & & $\mathrm{I}: 1$ & & & III:2 & $\mathrm{V}: 2$ & $\mathrm{~V}: 2$ & IV:2 & & & \\
\hline Molinia caerulea ssp. caerulea & & & & & III:2 & & & & $\mathrm{r}: 2$ & $\mathrm{~V}: 2$ & IV:2 & IV:2 & & \\
\hline Viola palustris ssp. palustris & & & & & & & & & & & $\mathrm{V}: 2$ & & & \\
\hline Parnassia palustris & & & & & & & & & & $\mathrm{r}: 2$ & $\mathrm{~V}: 2$ & & & \\
\hline Narthecium ossifragum & & & & & $\mathrm{r}:+$ & & & & & $\mathrm{II}: 2$ & IV:2 & & & \\
\hline Juncus acutiflorus & & & & & & & & & & & $\mathrm{II}: 1$ & $\mathrm{~V}: 3$ & & \\
\hline Eriophorum angustifolium & & & & & & & & & & IV:2 & $\mathrm{II}: 2$ & IV:2 & & \\
\hline Carex echinata & & & & & & & & & & IV:2 & III: 1 & III:2 & & \\
\hline Carum verticillatum & & & & $\mathrm{I}:+$ & $\mathrm{I}:+$ & & & & & III: + & $\mathrm{V}: 1$ & $\mathrm{II}: 2$ & & \\
\hline Wahlenbergia hederacea & & & & & $\mathrm{r}: 1$ & & & & & II: 1 & III:2 & & & \\
\hline Juncus effusus & III:2 & & II: + & & & $\mathrm{r}:+$ & $\mathrm{r}: 2$ & & & $\mathrm{r}: 1$ & $\mathrm{II}:+$ & III:2 & $\mathrm{V}: 5$ & II: 3 \\
\hline Agrostis capillaris & III:2 & $\mathrm{V}: 2$ & $\mathrm{~V}: 2$ & $\mathrm{~V}: 2$ & III:2 & $\mathrm{V}: 2$ & III:2 & II:1 & & $\mathrm{II}: 2$ & III: 1 & IV:2 & III: 1 & $\mathrm{II}: 2$ \\
\hline Pteridium aquilinum & & & II: + & $\mathrm{r}:+$ & $\mathrm{I}: 1$ & II:2 & & & $\mathrm{r}: 1$ & & & & $\mathrm{r}: 3$ & $\mathrm{~V}: 4$ \\
\hline
\end{tabular}

Names are given according to the main featuring species (grey bars). Each elementary syntaxon is described by a specific list of species (differential species in grey). Only the differential species are listed Relative frequency (RF) classes are indicated for each species in each syntaxon; r: species represented in less than $10 \%$ of the relevés or in a single relevé; I: $10 \% \leq \mathrm{RF} \leq 20 \%$; II: $20 \% \leq \mathrm{RF} \leq 40 \%$; III: $40 \%$ $<\mathrm{RF} \leq 60 \%$; IV: $60 \%<\mathrm{RF} \leq 80 \%$; V: RF $>80$. Mean abundance-dominance values are also indicated according to the Braun-Blanquet scale. The syntaxa are: H1, Urtica dioica-Cirsium palustre; $\mathrm{H} 2$, Rumex obtusifolius-Poa annua; H3, Trifolium repens-Poa annua; $\mathrm{H} 4$, Rumex acetosella-Galium saxatile; H5, Potentilla erecta-Agrostis curtisii; H6, Vaccinium myrtillus-Deschampsia flexuosa; H7, Oxalis acetosellaDeschampsia fexuosa; H8, Calluna vulgaris-Vaccinium myrtillus; H9, Ulex europaeus-Calluna vulgaris; H10, Molinia coerulea-Erica tetralix; H11, Viola palustris-Parnassia palustris; H12, Juncus acutiflorus-Eriophorum angustifolium; H13, Juncus effusus-Agrostis capillaris; H14, Pteridium aquilinum-Agrostis curtisii.

partial RDA ordination diagram of 61 pollen assemblages and 13 explanatory variables such as vegetation units and other environmental variables was performed (Figure 4).

Axis 1 shows a clear gradient from open land to forest vegetation types. It contrasts open land such as $\mathrm{CoE}$ No. 7, usually treeless dry heathland, with wooded sites, such as more or less open beech forest. CoE No. 7 and the North are respectively correlated, negatively $(r=-0.42)$, and positively $(r=0.47)$, to axis 1 . Indeed, beech forests, represented by $\mathrm{CoE}$ No.9, 10 and 11 included as passive variables, are generally found on northern slopes. Axis 2 appears to represent a soil richness gradient, and is positively linked with loss on ignition and total $\mathrm{N}$ ( $r=0.40$ and 0.36 , respectively), whereas the vegetation type CoE No. 12, oak forest on poor soils, presents a negative correlation $(r=-0.37)$. Thus, axis 2 contrasts the nitrophilous features of an overtrampled community (CoE No. 3 ) with oak forest. Axis 3 better expresses a grazing pressure gradient with sites intensively grazed and trampled on the positive side on the axis. CoE No. 2, an overgrazed community, is strongly linked with axis $3(r=0.50)$ and correlated to 
Table 2 Synthetic presentation of the elementary coenotaxa that constitute the Iraty mountains pastoral landscape

\begin{tabular}{|c|c|c|c|c|c|c|c|c|c|c|c|c|c|}
\hline Coenotaxon no. & 1 & 2 & 3 & 4 & 5 & 6 & 7 & 8 & 9 & 10 & 11 & 12 & 13 \\
\hline Number of phytocoenotic relevés & 3 & 3 & 3 & 4 & 6 & 9 & 15 & 4 & 6 & 7 & 6 & 4 & 1 \\
\hline H2 Rumex obtusifolius-Poа аппиа & $\mathrm{V}: 4$ & & & & & & & & & & & & \\
\hline H1 Urtica dioica-Cirsium palustre & $\mathrm{V}: 3$ & & & & & & & & & & & & \\
\hline H3 Trifolium repens-Pоа аппиа & & $\mathrm{V}: 3$ & & & & & & & $\mathrm{r}: 2$ & & & & \\
\hline H4 Rumex acetosella-Galium saxatile & & $\mathrm{V}: 4$ & $\mathrm{~V}: 4$ & $\mathrm{~V}: 2$ & & & $\mathrm{r}: 4$ & & & & & & \\
\hline H13 Juncus effusus-Agrostis capillaris & & $\mathrm{r}: 4$ & & $\mathrm{~V}: 4$ & & & & & & & $\mathrm{r}: 4$ & & \\
\hline H11 Viola palustris-Parnassia palustris & & & & & $\mathrm{V}: 3$ & & & & & & & & \\
\hline H12 Juncus acutiflorus-Eriophorum angustifolium & & & & & $\mathrm{V}: 4$ & & & & & & & & \\
\hline H10 Molinia coerulea-Erica tetralix & & & & & IV:2 & & & & & & & & \\
\hline H8 Calluna vulgaris-Vaccinium myrtillus & & & & $\mathrm{r}: 4$ & & II:4 & $\mathrm{r}: 4$ & III:4 & $\mathrm{r}: 2$ & $r: 3$ & & & \\
\hline H5 Potentilla erecta-Agrostis curtisii & & & & & & $\mathrm{V}: 4$ & $\mathrm{~V}: 3$ & & & $\mathrm{r}: 2$ & & IV:3 & \\
\hline H9 Ulex europaeus-Calluna vulgaris & & & & & & & $\mathrm{V}: 3$ & & & & & $\mathrm{~V}: 3$ & \\
\hline H14 Pteridium aquilinum-Agrostis curtisii & & & $\mathrm{r}: 5$ & $\mathrm{r}: 3$ & & $\mathrm{r}: 2$ & $\mathrm{I}: 4$ & $\mathrm{~V}: 4$ & & & & & \\
\hline H6 Vaccinium myrtillus-Deschampsia flexuosa & & & & & & $\mathrm{r}: 3$ & $\mathrm{r}: 4$ & $\mathrm{~V}: 2$ & $\mathrm{~V}: 2$ & $\mathrm{~V}: 2$ & $\mathrm{r}: 1$ & III:2 & $\mathrm{V}: 2$ \\
\hline A15 Fagus sylvatica & & & & & & & & & $\mathrm{V}: 4$ & $\mathrm{~V}: 3$ & V:3 & & \\
\hline B19 Fagus sylvatica & & & & & & & & & & $\mathrm{V}: 2$ & IV:3 & & \\
\hline H7 Oxalis acetosella-Deschampsia flexuosa & & & & & & & & & & & $\mathrm{V}: 2$ & & \\
\hline A16 Quercus robur-Fagus sylvatica & & & & & & $\mathrm{r}: 2$ & & & & & & III:2 & \\
\hline A17 Quercus robur & & & & & & & & & & & & III:2 & \\
\hline B21 Quercus robur-Fagus sylvatica & & & & & & & $\mathrm{r}: 1$ & & & & & $\mathrm{r}: 3$ & \\
\hline B20 Fagus sylvatica-Abies alba & & & & & & & & & & & & & $\mathrm{V}: 3$ \\
\hline A18 Fagus sylvatica-Abies alba & & & & & & & & & & & & & $\mathrm{V}: 4$ \\
\hline
\end{tabular}

Each coenotaxon $(\mathrm{CoE})$ is described by a list of syntaxa, numbered according to Table 1 for the herb layers (H: 1-14); the tree (A: 15-18) and shrub (B: 19-21) syntaxa are not presented in detail (see explanation in Table 1). The dominant SyE are listed (grey bars). The coenotaxa are: $\mathrm{CoE}$ 1, cattle enclosure; $\mathrm{CoE} 2$, overgrazed lawn; $\mathrm{CoE} 3$, overtrampled lawn; $\mathrm{CoE} 4$, grazed wet vegetation; CoE 5, mire vegetation; $\mathrm{CoE}$ 6, heathland; $\mathrm{CoE}$ 7, encroached heathland; $\mathrm{CoE} 8$, fern fallow; $\mathrm{CoE}$ 9, open beech forest; $\mathrm{CoE}$ 10, semi-open beech forest; $\mathrm{CoE} 11$, dense beech forest; $\mathrm{CoE} 12$, semi-open oak forest; $\mathrm{CoE} 13$, isolated site.

pastoral activities (grazing and trampling). On the negative side of axis 3, sites from CoE No.7 and 12 are related to low grazing pressure.

The investigated vegetation types represent the major relevant gradients in the modern pollen data. The first three axes respectively correspond to CoE No. 7 (dry heathland), CoE No. 12 (semi-open oak forest) and CoE No.2 (overgrazed community). These vegetation units are clearly related to the degree of openness, soil richness and grazing pressure, respectively. Therefore, in an attempt to identify indicator taxa for each of these three ecological trends, these coenotaxa were used individually as main predictors in partial RDA. The resulting species scores were further considered variables in a principal component analysis (PCA). In the ordination diagram (Figure 5), Ericaceae, Erica tetralix, Sanguisorba minor, associated to Poaceae, are positively linked with the degree of openness. As expected, Fagus and Pinus are related to forested sites. Abies and Plantago sp. are also correlated to forested sites and soil richness (more obvious on the plots of axes 1 and 3 ). The taxon Potentilla type occurs mainly in wet conditions with Apiaceae. Other data show that Potentilla-type and Apiaceae are mainly found in the peatbogs (Mazier et al., unpublished data, 2005).

Cichorioideae, Ranunculaceae, Stellaria-type, Cirsium-type, Galium-type and Asteroideae, are connected with the grazing pressure, whereas Chenopodiaceae, Plantago lanceolata and Plantago major/media are negatively correlated to grazing pressure.

Urtica dioica, Rumex, Scrophulariaceae and Rubiaceae are associated with soil richness. Several taxa are found close to the axes origin, such as Rumex obtusifolius, Artemisia, Betula, Vaccinium-Rhododendron, Lotus-type and Fabaceae. This suggests that these pollen taxa have little relationship to the measured variables represented by the three selected coenotaxa. Indeed, they are commonly recorded in low abundance in most of the sites, and thus are not characteristic of the investigated vegetation types.

\section{Discussion}

\section{Herb and tree pollen representation}

The indices of Davis $\mathrm{A}, \mathrm{O}$ and $\mathrm{U}$ provide some basic information on the general pollen-vegetation relationships of the mosaic vegetation of the Iraty Mountains, such as heathland, pastoral vegetation, and oak and beech forest. Table 3 presents the results of previous studies, in particular of Bunting (2003) and Hjelle (1997) who give indices for main taxa from Scottish and Norwegian heath communities, respectively. Potentilla-type and Poaceae are strongly associated, and Cirsium-type, Pteridium aquilinum are weakly associated for the three data sets. Plantago major/media has been found unassociated and Plantago lanceolata over-represented in both the Pyrenees and Scottish data sets. These comparisons indicate that these indices can be applied widely to different regions and also to different habitats.

Several taxa commonly used as anthropogenic indicator taxa, which were lightly or not at all investigated in the local vegetation communities, are recorded at low values in a very high proportion $(60-90 \%)$ of the surface samples, such as Artemisia, Chenopodiaceae and Plantago lanceolata (the latter observed three times in the 71 vegetation relevés). This suggests that sporadic, low percentages of these taxa in palaeorecords need not necessarily be indicative of local pastoral activity, but may originate from long-distance transport.

Some discrepancies were observed between these three data sets, ie, Calluna vulgaris which is strongly associated in Bunting (2003) and associated in the Iraty data set (this study), and the Vaccinium-type which is strongly associated in Scotland and weakly associated in this study. Apiaceae, Rumex, 


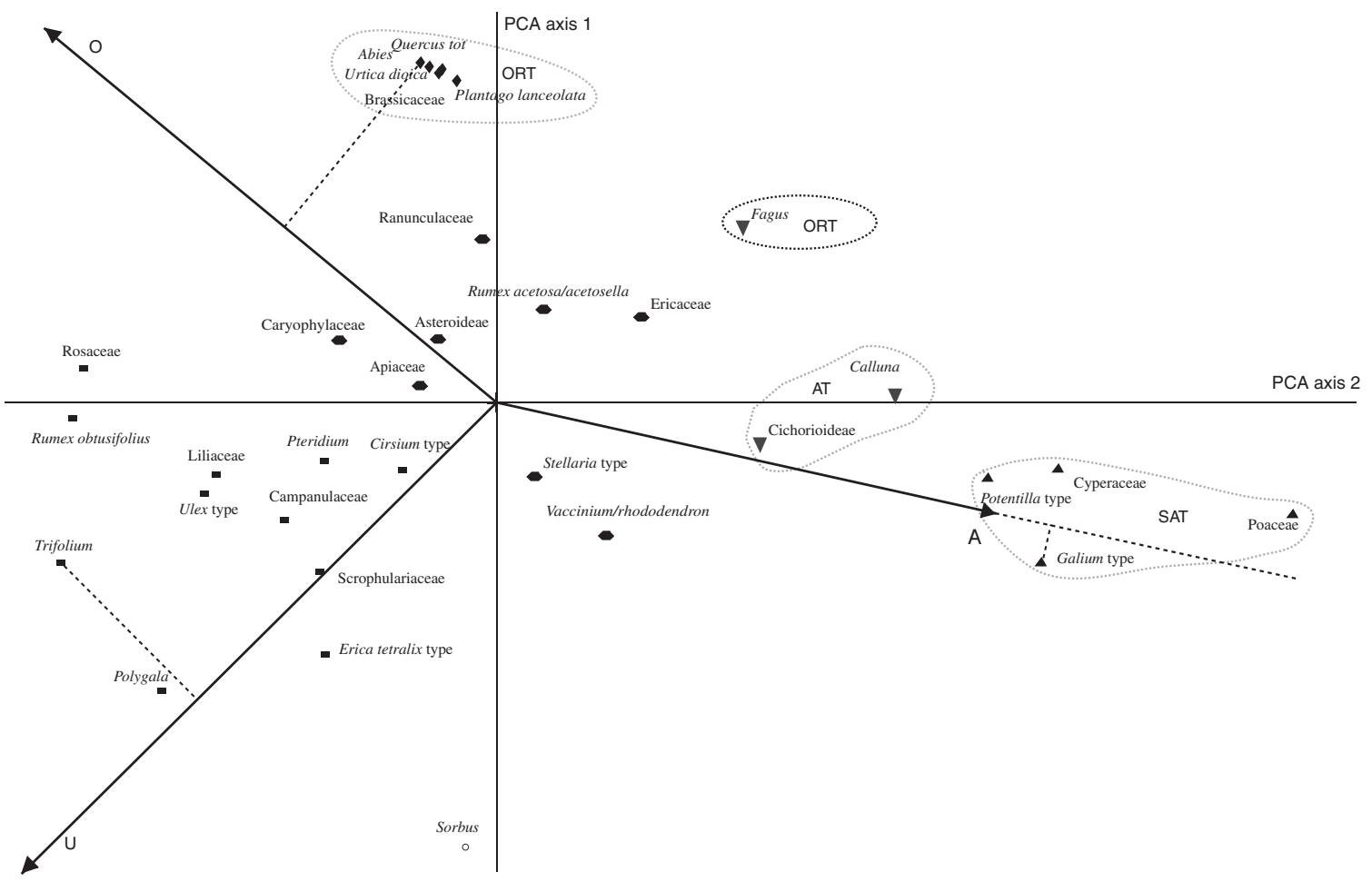

Figure 3 Principal Component Analysis (PCA) using Davis's indices of association (A), under-representation (U) and over-representation (O) (Davis, 1984). Groups according to the clustering are indicated with different symbols: $1, \diamond ; 2, \boldsymbol{O} ; 3, \boldsymbol{\nabla} ; 4$, $\mathbf{\square} ; 5, \boldsymbol{\Lambda}$. The eigenvalues of the first three principal component axes are $0.135(55.9 \%), 0.099(40.9 \%)$ and $0.008(3.2 \%)$, respectively

Ranunculaceae are over-represented in Bunting's data set and weakly represented in this study, while the Trifolium-type is associated in Hjelle (1998) and weakly associated in this study.

The dissimilarities between the three data sets might be explained by differences in environmental factors between regions, such as climate, edaphic conditions and land use (Broström et al., 2004). Grazing influence on flowering and pollen production of grasses is well documented (Groenmanvan Waateringe, 1993; Hjelle, 1998), thus it may be that Poaceae produce less pollen in anthropogenic coenotaxa. Another explanation may be the differences in pollen production for species included in large taxonomic groups such as Poaceae, Apiaceae and Ranunculaceae (Broström, 2004). A further reason may be the differences in sampling design and in method used for vegetation inventories (Bunting and Hjelle, unpublished data, 2004).

Broström et al. (2004) calculated relative pollen productivity estimates (PPEs) for 11 herb taxa related to Poaceae (used as reference taxon) and compared PPEs for herbs (Broström et al.'s study) and trees (data set of Sugita et al., 1999). She showed that most herb taxa have higher PPEs than Poaceae, for example Calluna vulgaris, Rumex acetosa-type and Plantago lanceolata. It is outlined in many studies that the presence of Plantago lanceolata in fossil pollen assemblages should be interpreted with caution, especially in pastoral areas on crystalline substrate, such as in our case. This taxon is characterized by long-distance transport and may originate from a wider landscape, for example, from valley floors in our case. Cichorioideae and Cyperaceae have lower PPEs, whereas Potentilla-type and Rubiaceae (Galium-type) have relatively higher PPEs than Poaceae (Broström et al., 2004). We obtained similar results, showing that these taxa can be considered good local indicators and are important in inferring past land uses from local pollen diagrams. Broström et al. (2004) also showed that most of the common tree taxa such as Pinus, Quercus and Fagus produce six to eight times as much pollen per unit area as Poaceae. This emphasizes the underestimation of past open land from fossil records when translating the AP/NAP ratio into open areas (Sugita et al., 1999). The overestimation of Pinus is well known (Heim, 1970; Broström et al., 1998, 2004). Pine is considered a high pollen producer and a long-distance disperser, which implies a significant regional input. This explains the important proportion of pine recorded in all the 71 surface samples, Pinus presents high proportion in beech forest and in fern fallow with dense canopy of Pteridium aquilinum (Mazier et al., unpublished data, 2005). Pteridium aquilinum forms a closed canopy at four sites grouped into the CoE No. 8 community, dominated by Pteridium aquilinum and Agrostis curtisï. It is surprising that Pteridium spores were not found in the pollen samples from these four sites, whereas it occurred in high proportion in one site of CoE No. 9 (more than $20 \%$ ), just before a small mountain dominated by this species. This may be due to preferential spore dispersal in relation to prevailing winds. The interpretation of Pteridium occurrence in pollen diagrams should be interpreted with caution (Tinsley, 2001).

We must keep in mind that, because of annual variability in pollen productivity, the use of moss polsters could be critical when studying pollen-vegetation relationships, and identifying pollen indicators of plant communities. Interannual variation in pollen productivity is well documented, at least for tree taxa, and has been shown to be related to climatic variability (Hicks, 2001; B. Odgaard, personal communication, 2004). Moreover, the exact number of deposition years in a moss polster is not known and differs from 1 to 10 years according to the authors (Heim, 1970; Bradshaw, 1981; Cundill, 1991; Räsänen et al., 2004). Räsänen et al. (2004) suggest that pollen assemblages in the green part of moss polsters represent more than one but less than two years of pollen deposition.

\section{Correlative model of pollen/vegetation/ environment relationships}

We focused on the pollen/plant/environment relationships as explored by Redundancy Analysis (a detailed presentation of 
Table 3 Indices of association and representation from three different studies (this study; Bunting, 2003; and Hjelle, 1997) based on the classification of Bunting (2003)

\begin{tabular}{|c|c|c|c|c|c|}
\hline Pollen taxon & A & $\mathrm{U}$ & $\mathrm{O}$ & Bunting (2003) & Hjelle (1997) \\
\hline \multicolumn{6}{|l|}{ Unassociated types (UT) } \\
\hline Anagallis & 0.00 & 1.00 & 1.00 & & \\
\hline Centaurea jacealnigra & 0.00 & 1.00 & 1.00 & & \\
\hline Fabaceae & 0.00 & 1.00 & 1.00 & UT & \\
\hline Ilex & 0.00 & 1.00 & 1.00 & & \\
\hline Labiatae & 0.00 & 1.00 & 1.00 & & \\
\hline Lotus-type & 0.00 & 1.00 & 1.00 & & WAT \\
\hline Parnassia-type & 0.00 & 1.00 & 1.00 & & \\
\hline Plantago major/media & 0.00 & 1.00 & 1.00 & no plant & WAT \\
\hline \multicolumn{6}{|c|}{ Strongly associated types (SAT) } \\
\hline Poaceae & 0.96 & 0.01 & 0.03 & SAT & SAT \\
\hline Cyperaceae & 0.73 & 0.10 & 0.20 & AT & \\
\hline Galium-type & 0.72 & 0.22 & 0.10 & Rubiaceae ORT & AT \\
\hline Potentilla-type & 0.67 & 0.16 & 0.23 & SAT & AT \\
\hline \multicolumn{6}{|l|}{ Associated types (AT) } \\
\hline Calluna & 0.58 & 0.12 & 0.38 & SAT & ORT \\
\hline Comp. SF Cichorioideae & 0.48 & 0.27 & 0.41 & & SAT \\
\hline \multicolumn{6}{|c|}{ Over-represented types (ORT) } \\
\hline Abies & 0.04 & 0.00 & 0.96 & & \\
\hline Urtica dioica & 0.05 & 0.00 & 0.95 & no plant & no plant \\
\hline Plantago lanceolata & 0.06 & 0.00 & 0.94 & ORT & SAT \\
\hline Brassicaceae & 0.06 & 0.00 & 0.94 & no plant & WAT \\
\hline Quercus tot. & 0.08 & 0.00 & 0.92 & & \\
\hline Fagus & 0.38 & 0.00 & 0.62 & & \\
\hline \multicolumn{6}{|c|}{ Under-represented types (URT) } \\
\hline Sorbus & 0.11 & 0.89 & 0.00 & & \\
\hline \multicolumn{6}{|c|}{ Weakly associated types (WAT) } \\
\hline Polygala & 0.03 & 0.97 & 0.50 & no pollen & URT \\
\hline Trifolium & 0.06 & 0.93 & 0.80 & & SAT (Trifolium repens type) \\
\hline Erica tetralix-type & 0.16 & 0.82 & 0.44 & & SAT \\
\hline Rumex obtusifolius & 0.05 & 0.75 & 0.95 & ORT (Rumex) & no plant \\
\hline Scrophulariaceae & 0.19 & 0.74 & 0.57 & & \\
\hline Ulex-type & 0.14 & 0.74 & 0.77 & & \\
\hline Campanulaceae & 0.18 & 0.71 & 0.67 & & AT \\
\hline Liliaceae & 0.14 & 0.71 & 0.78 & no plant & \\
\hline Rosaceae & 0.02 & 0.67 & 0.98 & & \\
\hline Pteridium & 0.20 & 0.61 & 0.71 & WAT & WAT \\
\hline Cirsium-type & 0.25 & 0.56 & 0.64 & WAT & WAT \\
\hline Vaccinium/Rhododendron & 0.38 & 0.49 & 0.41 & SAT (Vaccinium type) & WAT (Vaccinium type) \\
\hline Stellaria-type & 0.33 & 0.47 & 0.53 & & \\
\hline Apiaceae & 0.23 & 0.44 & 0.71 & ORT & SAT \\
\hline Caryophyllaceae & 0.16 & 0.44 & 0.81 & no plant & \\
\hline Comp. SF Asteroideae & 0.23 & 0.37 & 0.74 & & AT (Achillea type) \\
\hline Rumex acetosalacetosella & 0.28 & 0.25 & 0.69 & ORT (Rumex) & SAT \\
\hline Ranunculaceae & 0.20 & 0.20 & 0.79 & ORT (Ranunculus acris type) & SAT (Ranuculus acris type) \\
\hline Ericaceae & 0.35 & 0.19 & 0.61 & & \\
\hline
\end{tabular}

Indices of association (A), over-representation (O) and under-representation (U) for taxa present in both plant and pollen data sets. Strongly associated types: $\mathrm{A}>65 \%$; Associated types: $50 \%<\mathrm{A}<65 \%$; Over-represented types: low A values, high $\mathrm{O}$ values and $\mathrm{U}=0$; Weakly associated types: low A values and relatively high values for both $\mathrm{U}$ and $\mathrm{O}$; Unassociated types: $\mathrm{A}=0$ and high $\mathrm{O}$ and $\mathrm{U}$ values.

the pollen-diagram will be published elsewhere; Mazier et al., unpublished data, 2005).

Advantage of a synusial approach for studying vegetation The significant explanatory variables of the canonical axes were edaphic conditions (total $\mathrm{N}$, loss on ignition, $\mathrm{pH}$ ), geomorphology (aspect North, linked to forested sites), plant communities (CoE No. 2, 3, 4, 6, 7, 8 and 12) and land use (grazing, trampling). The results show that the vegetation units under consideration, which better reflect vegetation structure than a classical relevé, can be used efficiently to explain the major environmental gradients in pollen data. Dry heathland, semi-open oak forest and overgrazed community best reflect the gradients of landscape openness, soil richness and grazing pressure, respectively. RDA axis 1 separates open land from beech sites (both lightly grazed) that are contrasted mainly on the basis of Poaceae and Fagus. Poaceae is mainly represented in the CoE No. 7 community, a dry heathland corresponding to an early succession stage of the Ulex europaeus invasion. Broström et al. (1998) demonstrated that Poaceae may be representative of all types of open land. However, this study shows a difference in the proportion of Poaceae within vegetation types induced by human activity, since this taxon decreases in both the overgrazed CoE No. 3 and No. 2 
(a)

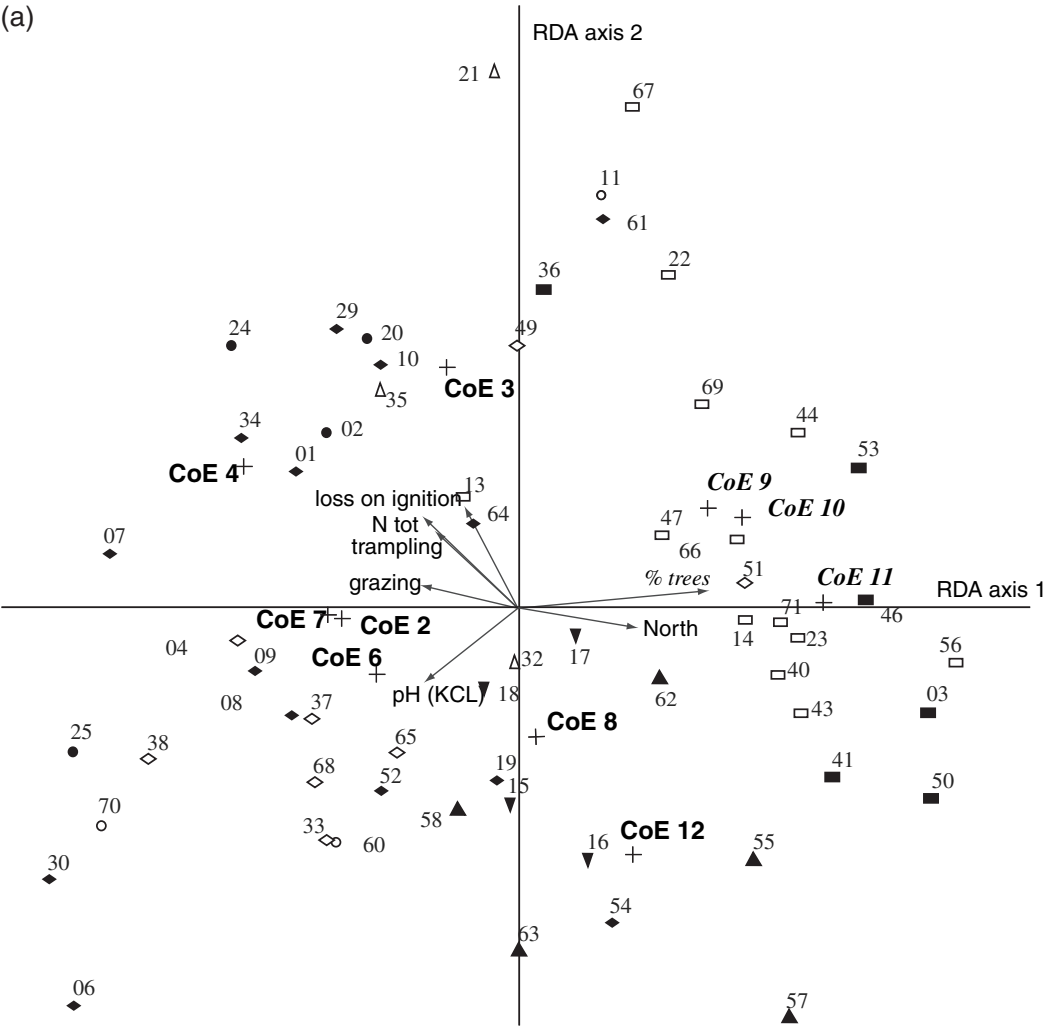

(b)

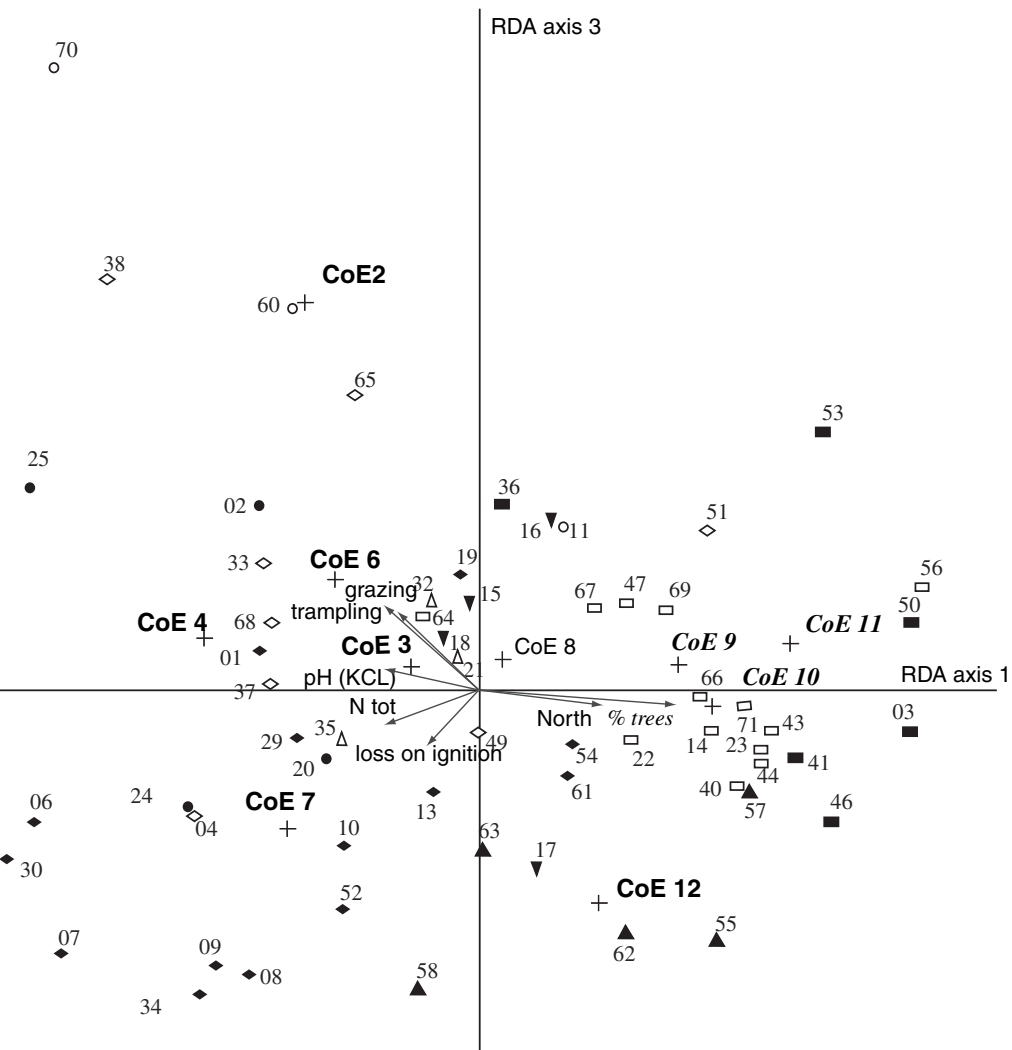

Figure 4 Redundancy analysis (RDA) of the modern pollen assemblages, using 13 explanatory variables (nominal variables are given with their centroïds (crosses) and quantitative variables with arrows), four passive variables (italic) and 61 pollen samples (points). The three first axes explain respectively $17.9,6.2$ and $5.4 \%$ of the total variation in the modern pollen data, and are all significant $(P<0.001$ after 999 permutations). The vegetation types, ie, elementary Coenotaxa (CoE) are: $\bigcirc, \mathrm{CoE} 2 ; \triangle, \mathrm{CoE} 3 ; \boldsymbol{\bullet}, \mathrm{CoE} 4 ; \diamond, \mathrm{CoE} 6 ; \diamond, \mathrm{CoE} 7 ; \boldsymbol{\nabla}$, CoE8; $\square$, CoE9/10; $\mathbf{\square}$, CoE11; $\boldsymbol{\Delta}$, CoE12. (a) Sites scores and environmental variables on RDA axes 1 and 2. (b) Site scores and environmental variables on RDA axes 1 and 3 


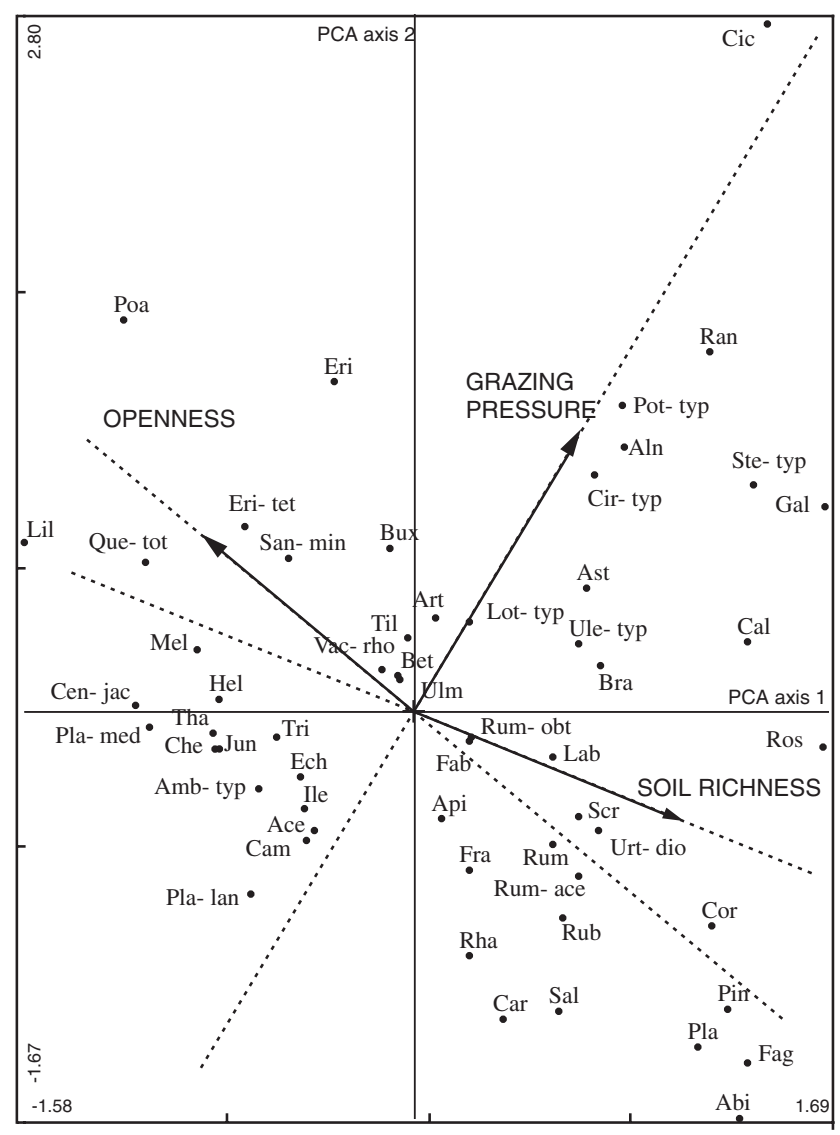

Figure 5 Principal Component Analysis (PCA) using the scores of a separate RDA with coenotaxa CoE No. 7 (dry heahland), indicative of vegetation openness, CoE No. 12 (semi-open oak forest), indicative of low soil richness, and CoE No. 2 (overgrazed community), indicative of high grazing pressure. Axis 1 and 2 represent $85 \%$ of the total variance. Abbreviations: Abi, Abies; Ace, Acer; Aln, Alnus; Amb-typ, Ambrosia-type; Api, Apiaceae; Art, Artemisia; Ast, Asteroideae; Bet, Betula; Bra, Brassicaceae; Bux, Buxus; Cal, Calluna; Cam, Campanulaceae; Car, Caryophyllaceae; Cen-jac, Centaurea jacea; Che, Chenopodiceae; Cic, Cichoriodeae; Cir-typ, Cirsium-type; Cor, Corylus; Ech, Echium; Eri, Ericaceae; Eri-tet, Erica tetralix; Fab, Fabaceae; Fag, Fagus; Fra, Fraxinus; Gal, Galium-type; Hel, Helianthemum;, Ile, Ilex; Jun, Juncus; Lab, Labiateae; Lil, Liliaceae; Lot-typ, Lotus type; Mel, Melampyrum; Poa, Poaceae; Pla, Plantago; Pla-lan, Plantago lanceolata; Pla-med, Plantago major/media; Pin, Pinus; Que-tot, Quercus total; Pot-typ, Potentilla type; Ran, Ranunculaceae; Rha, Rhamnus; Rub, Rubiaceae; Rum, Rumex; Rum-ace, Rumex acetosalacetosella; Rum-obt, Rumex obtusifolius; Ros, Rosaceae; Sal, Salix; San-min, Sanguisorba minor; Scr, Scrophulariaceae; Ste-typ, Stellaria type; Til, Tilia; Ulex-typ, Ulex type; Ulm, Ulmus; Urt-dio, Urtica dioica; Vac-rho, Vaccinium/Rhododendron

communities. Nevertheless, the proportion of Poaceae is not the same in CoE No. 2, an overgrazed pasture and CoE No. 4, grazed wet vegetation. The integrated synusial approach provides some explanation for these dissimilarities between pastoral communities. Poaceae was mainly recorded in $\mathrm{CoE}$ No. 4 and 7, and indeed this may be explained by the presence of patches of Juncus effusus (CoE No. 4) and Ulex europaeus (CoE No. 7), both of which protect herbs from grazing, thus allowing the flowering of the grasses. Alternatively, another factor might be the animals' preference for some species. This seems to be verified for Poa апnиa, the main species in $\mathrm{CoE}$ No. 2 that has a higher pastoral value and a higher appetency as compared with Agrostis curtisi. Another explanation might be the differences in pollen productivity of the various species included in this large taxonomic group. High grazing pressure induces a specific community, such as $\mathrm{CoE}$ No. 2, which presents patches of syntaxon H4 (Rumex acetosella-Galium saxatile) on nearly bare soils, and syntaxon H3 (Trifolium repens-Poа аппиа) in densely grazed micro-sites. This coenotaxon seems to be the most reliable analogue for intensive pastoral activity. On the other hand, CoE No. 7 can be used as an analogue for extensive pastures and CoE No. 9, 10 or 11 for deciduous, mainly beech, forest. CoE No. 6 provides a situation of transition between extensive and intensive pastures. CoE No. 3 and 4 are more related with the soil richness, which may derive from grazing pressure.

\section{Pollen indicators of pastoral activities}

In the PCA analysis based on the three vegetation predictors CoE No. 7, 12 and 2, Cichorioideae, Ranunculaceae, Stellariatype, Cirsium-type, Galium-type, Asteroideae and, to a lesser extent, Potentilla-type are strictly related to grazing pressure. Similar results were obtained in northern Europe (Hicks, 1988; Gaillard et al., 1992, 1994; Hjelle, 1998, 1999a,b; Räsänen, 2001). It was found that Cichorioideae (Hjelle, 1999a), Cirsium-type (Hjelle, 1998), Galium-type (Gaillard et al., 1992), Potentilla-type (Gaillard et al., 1992; Hjelle, 1999a), and Ranunculaceae (Hjelle, 1999a) were characteristic of grazing. In this study Plantago lanceolata, Chenopodiaceae and Plantago major/media, the last two taxa being absent from the vegetation, are more common in sites on aspects $\mathrm{N}$ and NW and occur mainly in lightly grazed wooded sites. Their presence is related to the prevailing wind, which brings pollen from a wider landscape. Gaillard et al. (1992) showed that Plantago lanceolata is a mowing indicator in southern Sweden. According to Hicks and Birks (1996), Chenopodiaceae and Rumex acetosalacetosella are related to human settlements. This may apply in our case for Rumex acetosalacetosella, since this taxon was present in tracks and/or in the ploughed soils of CoE No. 3, but generally it was recorded sporadically in modern pollen assemblages and therefore cannot be a good pastoral indicator. In our case, the presence of the taxa Chenopodiaceae, Plantago lanceolata and Artemisia implies regional input.

Urtica dioica is related to soil richness (total $\mathrm{N}$ and loss on ignition) and does not constitute a strict pastoral indicator (Gaillard et al., 1992), at least when low values are recorded (Mazier et al., unpublished data, 2005). It is found in surface samples from enclosures, but the plant often grows outside, where dung has accumulated near stone walls.

\section{Conclusion}

(1) The correlative model, RDA of 61 modern pollen spectra and 35 external variables, shows that wooded, opened, grazed and nitrophilous sites are clearly separated from each other. The relevant variables are vegetation types CoE No. 7 (dry heathland), CoE No. 12 (semi-open oak forest) and CoE No. 2 (overgrazed community). These vegetation units are clearly related to degree of openness, soil richness and grazing pressure, respectively. Therefore, the synusial integrated approach does provide a robust method for assessing vegetation structure and links between different patches (herbs, shrubs and trees), and also for relating modern pollen assemblages to environmental conditions.

(2) The present study implies that, when reconstructing past pastoral activity, it is important to identify the scale of the landscape in question. In our case, Artemisia, Chenopodiaceae, Plantago lanceolata, and Plantago major/media indicate regional human activity, and are not characteristic 
of specific land use, whereas the simultaneous presence, in pollen assemblages, of Asteroideae, Cichoriodeae, Cirsiumtype, Galium-type, Ranunculaceae, Stellaria-type and Potentilla-type is clearly associated with grazing on a local scale. Calculation of Davis indices also shows that Cichorioideae, Galium-type and Potentilla-type indicate very local presence of the corresponding plants. However, such pastoral indicators might be valid only for crystalline bedrock, and for this mountainous region.

(3) The final aim of our project is to achieve a more precise reconstruction of the cultural landscape in this mountainous area on a local scale, comparing the modern pollen assemblages to local fossil pollen assemblages from a small bog (Galop et al., 2003; Mazier et al., unpublished data, 2005). Thanks to the interdisciplinary research programme 'Palaeoenvironment and dynamics of human activities in the Pyrenees Mountains' this site is now also well documented in microfossil, historical and archaeological data. All these data sets will be used to validate the results of the comparative approach.

\section{Acknowledgements}

This study was possible thanks to the help of a number of people to whom we are very grateful: Didier Galop for pollen analysis, Cécile Brun for her precious assistance and encouragement during fieldwork, Pascal Vittoz and François Gillet for their advice on the integrated synusial approach and vegetation analysis, Jean-Daniel Tissot for computer programming, Anne Vignot for her permanent encouragement and Isabelle Jouffroy for guidance in the use of the End-note software. Christine Rendu and her archaeological staff, Onesime Prudhom and Bertrand Lagoguet, provided cheerful fieldwork. Thanks are due to Kari Hjelle for advice and corrections on the Davis Indices and to John Olsen for his improvement of the English text. The manuscript was improved thanks to the helpful comments and suggestions from the two referees, Sheila Hicks and Marie-José Gaillard. This investigation is a contribution to the project of the collective research program 'Paléoenvironnement et dynamiques de l'anthropisation en montagne basque' (Ministry of Culture and SRA Aquitaine), and the ATIP-CNRS 'Paléoenvironnement et Archéologie pastorale'.

\section{References}

Anderson, J.M. and Ingram, J.S.I. 1993: Tropical soil biology and fertility. A handbook of methods. 2nd edition. CAB International. Behre, K.E. 1981: The interpretation of anthropogenic indicators in pollen diagrams. Pollen et Spores 23, 225-45.

Berglund, B.E. and Ralska-Jasiewiczowa, M. 1986: Pollen analysis and pollen diagrams. In Berglund, B.E., editor, Handbook of Holocene palaeoecology and palaeohydrology. John Wiley \& Sons Ltd, 155-484

Berglund, B.E., Persson, T., Emanuelsson, U. and Persson, S. 1986 : Pollen/vegetation relationships in grazed and mowed plant communities of South Sweden. In Behre, K.-E., editor, Anthropogenic indicators in pollen diagrams. Balkema, 37-51.

Boyd, W.E. 1986: The role of mosses in modern pollen analysis: the influence of moss morphology on pollen entrapment. Pollen et spores XXVIII, 243-56.

Bradshaw, R.H.W. 1981: Modern pollen representation factors for woods in South-West England. Journal of Ecology 69, 45-70.

Braun-Blanquet, J. 1964: Pflanzensoziologie. Grundzüge der Vegetationskunde. Springer, 865.
Broström, A., Gaillard, M.-J., Ihse, M. and Odgaard, B. 1998: Pollen-landscape relationships in modern analogues of ancient cultural landscapes in southern Sweden - a first step towards quantification of vegetation openness in the past. Vegetation History \& Archaeobotany 7, 189-201.

Broström, A., Sugita, S. and Gaillard, M.-J. 2004: Pollen productivity estimates for the reconstruction of past vegetation cover in the cultural landscape of southern Sweden. The Holocene $14,368-81$.

Bunting, M.J. 2003: Pollen-vegetation relationships in non-arboreal moorland taxa. Review of Palaeobotany and Palynology 125, 285-98.

Casgrain, P. and Legendre, P. 2001: The R package for multivariate and spatial analysis version 4.0 (development release 6) user's manual. Université de Montréal, 134.

Court-Picon, M., Buttler, A. and de Beaulieu, J.-L. 2005: Modern pollen-vegetation relationship in the Champsaur valley (French Alps) and their potential in the interpretation of fossil pollen records of past cultural landscapes. Review of Palaeobotany and Palynology 135, 13.

Cundill, P.R. 1991: Comparisons of moss polster and pollen trap data: a pilot study. Grana 30, 301-308.

Davis, O.K., 1984: Pollen frequencies reflect vegetation patterns in a Great Basin (USA) mountain range. Review of Palaeobotany and Palynology 40, 295-315.

Faegri, K. and Iversen, J. 1989: Textbook of pollen analysis. John Wiley, 328, pp.

Gaillard, M.-J., Birks, H.J.B., Emanuelsson, U. and Berglund, B.E. 1992: Modern pollen/land-use relationships as an aid in the reconstruction of past land-uses and cultural landscapes: an example from south Sweden. Vegetation History and Archaeobotany 1, 3-17.

Gaillard, M.-J., Birks H.J.B., Emmanuelson, U., Karlson, S., Lagerås, P. and Olausson, D. 1994: Application of modern pollen/land-use relationships to the interpretation of pollen diagrams - reconstruction of land-use history in south Sweden, 3000-0. Review of Palaeobotany and Palynology 82, 47-73.

Gaillard, M.-J., Birks, H.J.B., Karlsson, S. and Lagerås, P. 1997: Quantitative reconstruction of past land-use and soil conditions using the modern analogue approach - a case study in southern Sweden. PACT 50, 431-42.

Galop, D. 1998: La forêt, l'homme et le troupeau dans les Pyrénées. 6000 ans d'histoire de l'environnement entre Garonne et Méditerranée. Contribution palynologique. GEODE - Laboratoire d'écologie terrestre - Framespa, 285 pp.

Galop, D., Mazier, F., Lopez-Saez, J.-A. and Vannière, B. 2003: Palynologie et histoire des activités humaines en milieu montagnard. Bilan provisoire des recherches et nouvelles orientations méthodologiques sur le versant nord des Pyrénées. Archéologie du midi médiéval 21, 159-70.

Galop, D., Rendu, C., Barcet, H., Buttler, A., Campnajo, P., Cugny, C., Gauthie, E., Legaz, A., Lopez-Saez, JA., Mazier, F., Metailié, J.P., Dominique, S. and Vanniére, B. 2004: Paléoenvironenment et archéologie pastorale. Propositions méthodologiques pour une approche intégrée des modalités du l'anthropisation en haute montagne pyrénéenne du Néolithique à l'actuel. Besançon: UMR 6565 CNRS-Université de Franche-Cormté, 70 pp, unpublished. Gillet, F. and Gallandat, J.-D. 1996: Integrated synusial phytosociology: some notes on a new, multiscalar approach to vegetation analysis. Journal of Vegetation Science 7, 13-18.

Gillet, F., De Foucault, B. and Julve, P. 1991: La phytosociologie synusiale intégrée: objets et concepts. Candollea 46, 315-40.

Gillet, F., Besson, O. and Gobat, J.-M. 2002: PATUMOD: a compartment model of vegetation dynamics in wooded pastures. Ecological Modelling 147, 267-90.

Groenman-van Waateringe, W. 1993: The effect of grazing on the pollen production of grasses. Vegetation History and Archaeobotany 2, 157-62.

Heim, J. 1970: Les relations entre les spectres polliniques récents et la végétation actuelle en europe occidentale. Doctoral Thesis, Université de Louvain, 179 pp.

Hicks, S. 1988: The representation of different farming practices in pollen diagrams from northern Finland. In Birks, H.H., Birks, 
H.J.B., Kaland, P. and Dagfinn, M., editors, The cultural landscape - past, present and future. Cambridge University Press, 189-207. Hicks, S. 2001: The use of annual arboreal pollen deposition values for delimiting tree-lines in the landscape and exploring models of pollen dispersal. Review of Palaeobotany and Palynology $117,1-29$.

Hicks, S. and Birks, H.J.B. 1996: Numerical analysis of modern and fossil pollen spectra as a tool for elucidating the nature of fine-scale human activities in boreal areas. Vegetation History and Archaeobotany 5, 257-72.

Hicks, S., Tinsley, H., Huusko, A., Jensen, C., Hattestrand, M., Gerasimides, A. and Kvavadze, E. 2001: Some comments on spatial variation in arboreal pollen deposition: first records from the Pollen Monitoring Programme (PMP). Review of Palaeobotany and Palynology 117, 183-94.

Hjelle, K.L. 1997: Relationships between pollen and plants in human-influenced vegetation types using presence-absence data in Western Norway. Review of Palaeobotany and Palynology 99, 1-16. — 1998: Herb pollen representation in surface moss samples from mown meadows and pastures in Western Norway. Vegetation History and Archaeobotany 7, 79-96.

- 1999a: Modern pollen assemblages from mown and grazed vegetation types in western Norway. Review of Palaeobotany and Palynology 107, 55-81.

1999b: Use of modern pollen samples and estimated pollen representation factors as aids in the interpretation of cultural activity in local pollen diagrams. Norwegian Archaeological Review $32,19-39$.

Leps, J. and Smilauer, P. 2003: Multivariate analysis of ecological data using CANOCO. Cambridge University Press, 282, pp.

Moore, P.D., Webb, J.A. and Collinson, M.E. 1991: Pollen analysis. Blackwell Science, 216 pp.

Räsänen, S. 2001: Tracing and interpreting fine-scale human impact in northern Fennoscandia with the aid of modern pollen analogues. Vegetation History and Archaeobotany 10, 211-18.
Räsänen, S., Hicks, S. and Odgaard, B.V. 2004: Pollen deposition in mosses and in a modified 'Tauber trap' from Hailuoto, Finland: what exactly do the mosses record? Review of Palaeobotany and Palynology 129, 103-16.

Reille, M. 1992: Pollen et spores d'Europe et d'Afrique du Nord. Laboratoire de Botanique Historique et Palynologie, 535 pp.

Sugita, S., Gaillard M.-J. and Broström, A. 1999: Landscape openness and pollen records: a simulation approach. The Holocene 9, 409-21.

Ter Braak, C.J.F. and Prentice, C.I. 1988: A theory of gradient analysis. Advances in Ecological Research 18, 271-317.

Ter Braak, C.J.F. and Smilauer, P. 1998: CANOCO Reference manual. User's Guide to Canoco for Windows. Software for canonical community ordination (version 4). Centre for Biometry Wageningen, $352 \mathrm{pp}$.

Tinsley, H. 2001: Modern pollen deposition in traps on a transect across an anthropogenic tree-line on Exmoor, southwest England: a note summarising the first three years of data. Review of Palaeobotany and Palynology 117, 153-58.

Tutin, T.G., Heywood, V.H., Burges, N.A., Valentine, D.H., Walters, S.M., Webb, D.A. and with the assistance of Ball, P.W.a.C., A. O. 1964-1980: Flora Europea. Cambridge University Press.

van der Knaap, W.O., van Leeuwen, J.F.N. and Ammann, B. 2001: Seven years of annual pollen influx at the forest limit in the Swiss Alps studied by pollen traps: relations to vegetation and climate. Review of Palaeobotany and Palynology 117, 31-52.

Vorren, K.-D. 1986: The impact of early agriculture on the vegetation of Northern Norway. A discussion of anthropogenic indicators in biostratigraphical data. In Behre, K.-E. editor, Anthropogenic indicators in pollen diagrams, Balkema, 1-18.

Wildi, O. and Orloci, L. 1996: Numerical exploration of community patterns. Amsterdam: SPB Academic Publishing, $171 \mathrm{pp}$.

Wright, H.E.J. 1967: The use of surface samples in quaternary pollen analysis. Review of Palaeobotany and Palynology 2, 321-30. 